\title{
Petasiger Dietz, 1909 (Trematoda: Echinostomatidae) in Birds and Mollusks from Brazil
}

\author{
Petasiger Dietz, 1909 (Trematoda: Echinostomatidae) em aves e moluscos do Brasil \\ Hudson Alves Pinto ${ }^{1 *}$; Germán Arturo Bohórquez Mahecha²; Alan Lane de Melo ${ }^{1}$
}

\author{
${ }^{1}$ Departamento de Parasitologia, Instituto de Ciências Biológicas, Universidade Federal de Minas Gerais - UFMG, \\ Belo Horizonte, MG, Brasil \\ ${ }^{2}$ Departamento de Morfologia, Instituto de Ciências Biológicas, Universidade Federal de Minas Gerais - UFMG, \\ Belo Horizonte, MG, Brasil
}

Received March 18, 2013

Accepted May 9, 2013

\begin{abstract}
Species of Petasiger Dietz, 1909 are intestinal trematodes of aquatic birds. Despite the diversity of described species in Europe and North America, only two South American species are known and no species have been previously reported in birds from Brazil. During a study of helminths recovered from the Least Grebe, Tachybaptus dominicus (Linnaeus, 1766), from the state of Minas Gerais, Brazil, adult trematodes identified as Petasiger novemdecim Lutz, 1928 were found. The prevalence of infection was 55\% (5/9), and the mean intensity of infection was 8 (1-32) parasites. Additionally, Biomphalaria straminea (Dunker, 1848) and Biomphalaria tenagophila (d'Orbigny, 1835) obtained from aquatic collections in the same state were found to harbor two species of echinostome cercariae of the Magnacauda group. These cercariae developed into metacercariae in experimentally infected Poecilia reticulata Peters, 1859. Attempts to obtain adult parasites in vertebrate host models (mice, chickens, ducks and canaries) were unsuccessful. The present study is the first report of Petasiger in Brazilian birds and the first morphological description of larvae of these parasites in Brazilian mollusks. Taxonomic aspects related to South American species of Petasiger are discussed. It is suggested that, based on significant morphological differences observed in larval stages (i.e., larval dimensions) and adult parasites (i.e., disposition of the testes), Petasiger caribbensis Nassi, 1980 should be reconsidered as a distinct species from $P$. novemdecim.
\end{abstract}

Keywords: Trematodes, grebes, mollusks, cercariae, Petasiger, Brazil.

\section{Resumo}

Espécies do gênero Petasiger Dietz, 1909 são trematódeos intestinais de aves aquáticas. Apesar da diversidade de espécies descritas na Europa e América do Norte, somente duas espécies são conhecidas na América do Sul, e nenhuma espécie reportada previamente em aves do Brasil. Durante o estudo de helmintos recuperados de Mergulhão pequeno, Tachybaptus dominicus (Linnaeus, 1766), do estado de Minas Gerais, Brasil, trematódeos adultos identificados como Petasiger novemdecim Lutz, 1928 foram encontrados. A prevalência de infecção foi 55\% (5/9) e a intensidade média de infecção 8 (1-32) parasitos. Adicionalmente, Biomphalaria straminea (Dunker, 1848) e Biomphalaria tenagophila (d'Orbigny, 1835) obtidas em coleçóes aquáticas do mesmo estado foram encontradas albergando duas espécies de cercárias do tipo equinóstoma pertencentes ao grupo Magnacauda. Estas cercárias desenvolveram-se em metacercárias em Poecilia reticulata Peters, 1859 experimentalmente infectados. Tentativas de obtenção de parasitos adultos em modelos experimentais (camundongos, frangos, patos e canários) demonstraram-se sem sucesso. O presente estudo é o primeiro relato de Petasiger em aves brasileiras e primeira descrição morfológica de larvas destes parasitos em moluscos do Brasil. Aspectos taxonômicos relacionados às espécies sul-americanas de Petasiger são discutidos. Sugere-se que, em vista das diferenças morfológicas observadas nos estágios larvais (i.e., dimensóes das larvas) e dos parasitos adultos (i.e., disposição dos testículos), Petasiger caribbensis Nassi, 1980 seja reconsiderada espécie distinta de $P$. novemdecim.

Palavras-chave: Trematódeos, mergulhōes, moluscos, cercárias, Petasiger, Brasil.

\footnotetext{
${ }^{*}$ Corresponding author: Hudson Alves Pinto

Laboratório de Taxonomia e Biologia de Invertebrados, Departamento de

Parasitologia, Instituto de Ciências Biológicas, Universidade Federal de Minas

Gerais - UFMG, CP 486, CEP 30123-970, Belo Horizonte, MG, Brasil

e-mail: hudsonalves13@ig.com.br
} 
Species of the genus Petasiger Dietz, 1909 are intestinal trematodes of aquatic birds that are mainly found in grebes. This genus currently includes 19 valid species and has a worldwide distribution (KOSTADINOVA, 2005; FALTÝNKOVÁ et al., 2008; LUNASCHI; DRAGO, 2010). The life cycle of these parasites was elucidated by experimental infection studies and more recently with the aid of molecular approaches. Echinostome cercariae of the Magnacauda group are formed within planorbid mollusks. After emerging from the mollusks, cercariae display a fishing lure swimming behavior and are ingested by fish, in which they encyst in the oral cavity. Upon ingestion of the fish by fish-eating birds, the metacercariae develop into adult parasites in the small intestines of these hosts (BEAVER, 1939; ABDEL-MALEK, 1952, 1953; KOSTADINOVA; CHIPEV, 1992; GEORGIEVA et al., 2012).

Despite the diversity of species of Petasiger in Europe and North America, only two species have been identified in birds from South America: Petasiger novemdecim Lutz, 1928, described in the Least Grebe, Tachybaptus dominicus (Linnaeus, 1766) in Venezuela (LUTZ, 1928), and Petasiger argentinensis Lunaschi and Drago, 2010 described in both the Great Grebe, Podiceps major (Boddaert, 1783), and the White-Tufted Grebe, Rollandia rolland (Quoy and Gaimard, 1824) in Argentina (LUNASCHI; DRAGO, 2010). In addition, two undetermined species of Petasiger were reported in Argentina: Petasiger sp. 1 was found in the Cocoi Heron, Ardea cocoi Linnaeus, 1766, and Petasiger sp. 2 was recovered from the Black Vulture, Coragyps atratus (Bechstein, 1793) (DRAGO; LUNASCHI, 2011). Information regarding the occurrence of larval stages of Petasiger in South America is scarce. However, records are available of mollusks naturally infected with $P$. novemdecim in Venezuela (NASIR et al., 1972) and with Petasiger sp. in Argentina, Brazil, and Venezuela (MILWARDDE-ANDRADE; CAMPOS, 1969; OSTROWSKI DE NÚNEEZ, 1981; OSTROWSKI DE NÚNEEZ et al., 1991).

In the present study 9 specimens of $T$. dominicus that were collected by one of us (GABM) from locations in the state of Minas Gerais, Brazil, in the 1990s were evaluated for the presence of parasites. The birds were fixed in 10\% formalin, and the viscera were subsequently examined under a stereomicroscope. The digeneans were collected, stained with alum acetocarmine, dehydrated using an ascending ethanol gradient, cleared in beechwood creosote and mounted on permanent slides in Canada balsam.

Additionally, species of Biomphalaria Preston, 1910 were collected during malacological surveys carried out in water bodies in the state of Minas Gerais, Brazil, and examined for infection with larval trematodes. Some of these planorbids were found to harbor echinostome cercariae of the Magnacauda group. Rediae were recovered from naturally infected mollusks after they were pressed between glass slides and examined using a stereomicroscope. Laboratory-reared Poecilia reticulata Peters, 1859 were experimentally infected with cercariae following the protocol described by Pinto and Melo (2012). Metacercariae were obtained from the oral cavities of these fish 10 days after infection and force fed orally to experimental definitive hosts (mice, chickens, ducks, and canaries). These hosts were killed by cervical dislocation 5 days after infection, and their intestines were examined for the presence of parasites.
Parasite developmental stages were studied by light microscopy. Images were obtained using a Leica ICC50 HD digital camera attached to a light microscope. Measurements were obtained during microscopy using an ocular micrometer or after microscopy using Leica Application Suite (LAZ EZ) software version 2.0 (Leica Microsystem Ltd, Switzerland) to analyze captured images. Cercariae were studied using vital stains and were later killed in water at $70^{\circ} \mathrm{C}$ and fixed in $10 \%$ formalin solution. Parasites were identified using taxonomic keys and species descriptions from different authors (LUTZ, 1928; NASIR et al., 1972; NASSI, 1980; KOSTADINOVA, 2005; FALTÝNKOVÁ et al., 2008; LUNASCHI; DRAGO, 2010). Morphometric data, presented in micrometers, are given as the mean followed by the standard deviation and range in parentheses. Relationships (ratios) between measurements of the internal structures of adult parasites were determined according to Faltýnková et al. (2008) and Lunaschi and Drago (2010). The specimens studied were deposited in the collection of the Laboratory of Taxonomy and Biology of Invertebrates, Department of Parasitology, Federal University of Minas Gerais, Brazil, under the access number DPIC 2457-2459.

Among the 9 specimens of $T$. dominicus examined, 5 (55\%) were infected with trematodes identified as $P$. novemdecim (Figure 1). The mean intensity of infection was 8 parasites, with a range of 1-32. Morphometric data for adult parasites recovered from $T$. dominicus in the present study and previously reported measurements of species of Petasiger from South American birds are presented in Table 1 .

Malacological surveys of aquatic collections from the state of Minas Gerais, Brazil, revealed 2 species of Petasiger developing in Biomphalaria spp. (Figure 2a-d). Infection rates were generally low $(<0.1 \%)$. Larvae from Petasiger sp. 1 were found in Biomphalaria straminea (Dunker, 1848), while Petasiger sp. 2 was found in B. straminea and Biomphalaria tenagophila (d'Orbigny, 1835).

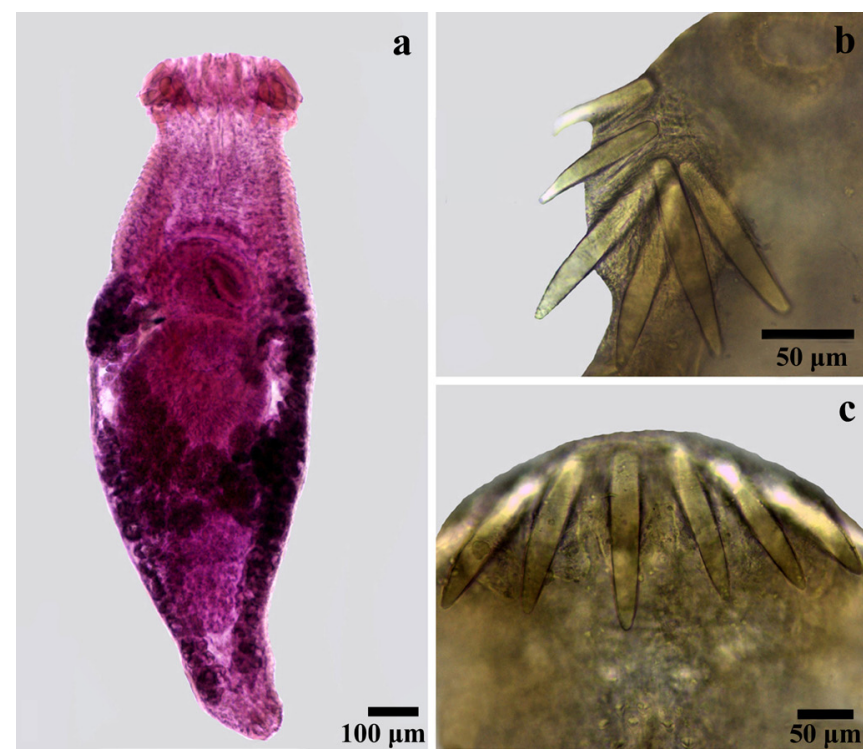

Figure 1. Petasiger novemdecim obtained from Tachybaptus dominicus in Brazil. (a) Adult parasite, entire view. (b) Detailed view of angle and lateral collar spines. (c) Detailed view of dorsal collar spines. 
Table 1. Morphometric data for Petasiger novemdecim recovered from Tachybaptus dominicus in Brazil and measurements presented by other authors for Petasiger species from South America. Abbreviations: BL = Body length, BW = Body width, CSW $=\mathrm{Cirrus}$ sac width, $\mathrm{L}=$ length, $\mathrm{E}=$ egg, PHW = pharynx width, ODIV = distance from anterior extremity to intestinal bifurcation, OSW = oral sucker width, VSW = ventral sucker width, VSL = ventral sucker length, $\mathrm{W}=$ width. ${ }^{*}$ Calculated from the drawing presented by Nassi (1980).

\begin{tabular}{|c|c|c|c|c|c|c|}
\hline \multirow{2}{*}{$\begin{array}{r}\text { Species } \\
\text { Reference }\end{array}$} & & \multicolumn{3}{|c|}{ Petasiger novemdecim } & \multirow{2}{*}{$\begin{array}{c}\text { P. caribbensis } \\
\text { Nassi, } 1980\end{array}$} & \multirow{2}{*}{$\begin{array}{c}\text { P. argentinensis } \\
\text { Lunaschi and Drago, } 2010\end{array}$} \\
\hline & & Present study & Nasir et al., 1972 & Faltýnková et al., 2008 & & \\
\hline Host & & T. dominicus & T. dominicus & T. dominicus & Canary & $\begin{array}{l}\text { Podiceps major } \\
\text { Rollandia rolland }\end{array}$ \\
\hline Locality & & Brazil & Venezuela & Venezuela & Guadalupe & Argentina \\
\hline \multirow[t]{2}{*}{ Body } & $\mathrm{L}$ & $1,125 \pm 54(1,066-1,213)$ & $1,211-1,577$ & 1,575 & $1,250-1,580$ & $970(890-1,060)$ \\
\hline & W & $349 \pm 45(294-407)$ & $448-564$ & 602 & $400-520$ & $347(286-396)$ \\
\hline \multirow[t]{2}{*}{ Collar } & $\mathrm{L}$ & $131 \pm 17(105-164)$ & - & 183 & - & $115(107-131)$ \\
\hline & W & $227 \pm 18(205-250)$ & $224-286$ & 325 & $210-270$ & $214(202-226)$ \\
\hline Angle spines & $\mathrm{L}$ & $114 \pm 8(93-129)$ & $72-130$ & $96-111$ & - & $80(67-95)$ \\
\hline Dorsal spines & $\mathrm{L}$ & $97 \pm 10(75-109)$ & $47-74$ & $84-90$ & $64-79$ & $52(43-62)$ \\
\hline Lateral spines & $\mathrm{L}$ & $78 \pm 7(66-88)$ & - & $68-69$ & $70-95$ & $52(48-57)$ \\
\hline \multirow[t]{2}{*}{ Oral sucker } & $\mathrm{L}$ & $78 \pm 7(67-90)$ & $72-84$ & 100 & $70-90$ & $68(62-80)$ \\
\hline & W & $65 \pm 6(57-71)$ & - & 94 & $70-106$ & $67(60-71)$ \\
\hline Prepharynx & $\mathrm{L}$ & $39 \pm 7(32-50)$ & $23-47$ & 53 & - & $30(15-45)$ \\
\hline \multirow[t]{2}{*}{ Pharynx } & $\mathrm{L}$ & $62 \pm 5(58-70)$ & $72-86$ & 83 & $57-78$ & $63(48-77)$ \\
\hline & W & $38 \pm 4(30-43)$ & $44-64$ & 53 & $41-58$ & $35(31-40)$ \\
\hline Esophagus & $\mathrm{L}$ & $143 \pm 17(116-161)$ & $156-180$ & 189 & - & $155(119-193)$ \\
\hline \multirow[t]{2}{*}{ Ventral sucker } & $\mathrm{L}$ & $273 \pm 45(205-328)$ & $224-288$ & 301 & $235-286$ & $306(256-338)$ \\
\hline & W & $225 \pm 26(198-264)$ & - & 325 & $235-264$ & $248(208-314)$ \\
\hline \multirow[t]{2}{*}{ Cirrus sac } & $\mathrm{L}$ & $186 \pm 26(150-205)$ & $197-248$ & 293 & - & $138(121-167)$ \\
\hline & W & $203 \pm 34(177-253)$ & $224-289$ & 348 & - & $156(107-195)$ \\
\hline \multirow[t]{2}{*}{ Ovary } & $\mathrm{L}$ & $76 \pm 10(61-89)$ & $120-159$ & 148 & $95-135$ & $67(54-81)$ \\
\hline & W & $71 \pm 10(55-82)$ & $110-122$ & - & $100-136$ & $66(52-82)$ \\
\hline Anterior & $\mathrm{L}$ & $111 \pm 7(102-116)$ & $140-168$ & 165 & $140-220$ & $77(68-87)$ \\
\hline testis & W & $154 \pm 14(137-171)$ & $200-249$ & 277 & $160-225$ & $138(119-159)$ \\
\hline Posterior & $\mathrm{L}$ & $121 \pm 18(102-137)$ & $168-179$ & 183 & $144-214$ & $82(57-101)$ \\
\hline testis & W & $147 \pm 20(130-171)$ & $160-186$ & 260 & $180-230$ & $115(100-126)$ \\
\hline \multirow[t]{2}{*}{ Eggs } & $\mathrm{L}$ & $72 \pm 4(70-78)$ & $60-72$ & - & $70-84$ & $81(75-90)$ \\
\hline & W & $39 \pm 2(37-42)$ & $30-44$ & - & $48-55$ & $48(36-58)$ \\
\hline ODIV & & $329 \pm 29(286-372)$ & - & - & $432^{*}$ & $277(231-312)$ \\
\hline ODIV/BL & & $0.29(0.25-0.33)$ & - & 0.27 & $0.27^{*}$ & - \\
\hline OSW/PHW & & $1.7(1.4-2.3)$ & - & 1.8 & $1.8^{*}$ & $1.9(1.7-2.2)$ \\
\hline CSW/BW & & $0.6(0.5-0.6)$ & - & 0.58 & $0.46^{*}$ & - \\
\hline CSW/VSW & & $1.0(0.9-1.3)$ & - & 1.07 & $0.77^{*}$ & - \\
\hline BW/VSW & & $1.6(1.4-1.7)$ & - & 1.9 & $1.8^{*}$ & $3.2(2.7-3.9)$ \\
\hline VSW/CSW & & $1.0(0.8-1.1)$ & - & 0.9 & $1.3^{*}$ & $1.6(1.1-2.2)$ \\
\hline $\mathrm{BL} / \mathrm{E}$ & & $15(14-16)$ & - & 20 & $20^{*}$ & $12(10-13)$ \\
\hline $\mathrm{BL} / \mathrm{VSL}$ & & $4.1(3.5-4.9)$ & - & 5.2 & $5.5^{*}$ & $3.2(2.7-3.9)$ \\
\hline
\end{tabular}

Cercariae from these 2 species have similar characteristics, such as the presence of a long tail, S-shaped movement, a body with a head collar bearing 19 spines, including 4 angle spines on each side, a pharynx area with a yellow-brown interior, and cystogenous gland-cells with rhabditiform contents covering the entire body posterior to the pharynx. Cercariae of Petasiger sp. 1 differ from Petasiger sp. 2 mainly in possessing a substantially smaller tail. The cercariae originate from yellow-orange elongated rediae that have a pair of locomotory appendages in the posterior region and a collar with 4 lobes in the anterior region. Rediae of Petasiger sp.
1 are smaller than those of Petasiger sp. 2. Metacercariae of both species were obtained from the oral cavity of experimentally infected P. reticulata; the metacercariae are oval and possess a thin external wall (Figure 2d-f). Cysts of Petasiger sp. 1 are significantly larger than those of Petasiger sp. 2. Although experimental attempts to infect birds and mammalian hosts were performed, adult parasites were not recovered. Measurements of developmental stages of both Petasiger species, including the cercariae and rediae obtained from mollusks and the metacercariae obtained experimentally from P. reticulata, are presented in Table 2 . 

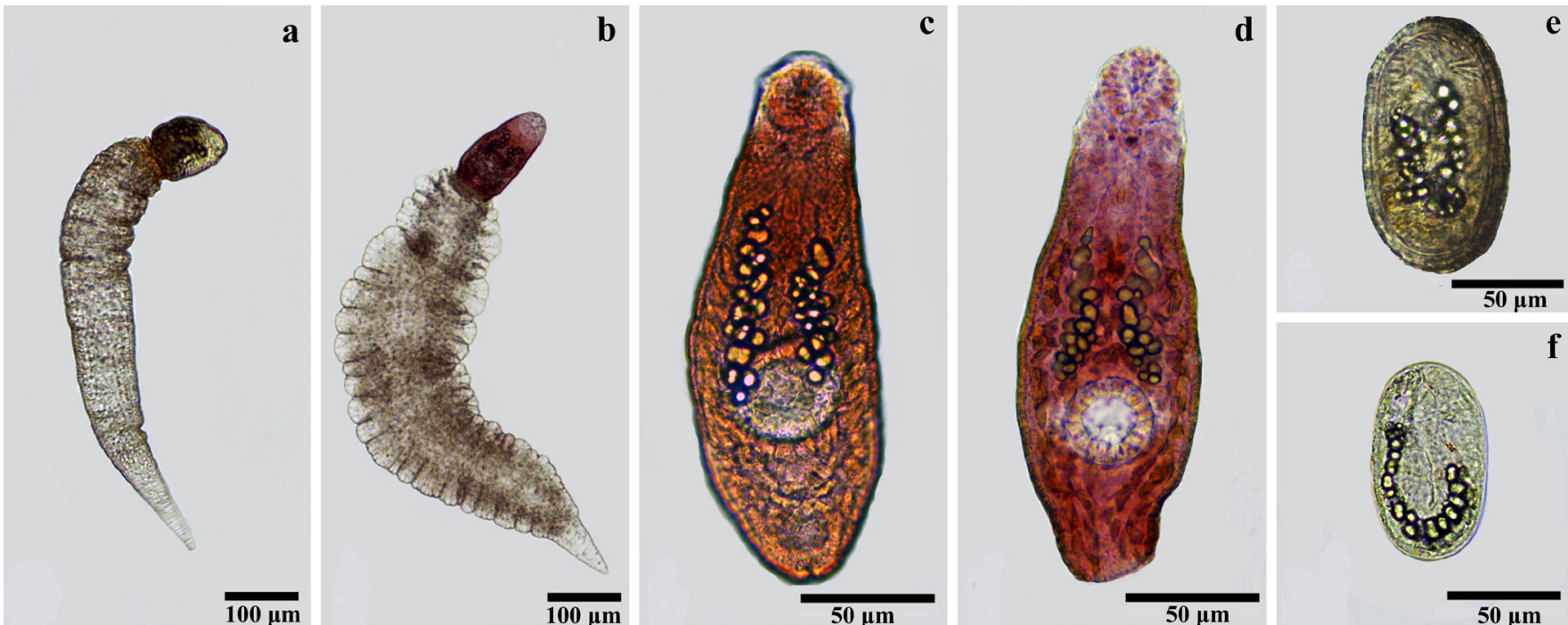

Figure 2. Cercariae and metacercariae of Petasiger spp. obtained from mollusks in Brazil. Petasiger sp. 1. (a, c, e). Petasiger sp. 2. (b, d, f). Total view of larvae $(\mathrm{a}, \mathrm{b})$. Detailed view of cercariae body $(\mathrm{c}, \mathrm{d})$. Total view of metacercariae obtained experimentally from Poecilia reticulata (e, f).

Table 2. Morphometric data for larval stages of Petasiger spp. obtained from Biomphalaria spp. in Brazil and measurements presented by other authors for similar larvae from the neotropics. Abbreviations: $\mathrm{L}=$ length, $\mathrm{N}=$ number, $\mathrm{W}=$ width.

\begin{tabular}{|c|c|c|c|c|c|c|c|}
\hline Species & & Petasiger sp. 1 & Petasiger sp. 2 & P. novemdecim & P. caribbensis & Petasiger sp. & Petasiger sp. \\
\hline Reference & & Present study & Present study & $\begin{array}{l}\text { Nasir et al., } \\
1972\end{array}$ & Nassi, 1980 & $\begin{array}{l}\text { Ostrowski de } \\
\text { Núñez, } 1982\end{array}$ & $\begin{array}{c}\text { Ostrowski de } \\
\text { Núñez et al., } 1991\end{array}$ \\
\hline Host & & B. straminea & $\begin{array}{l}\text { B. straminea, } \\
\text { B. tenagophila }\end{array}$ & B. glabrata & B. glabrata & B. glabrata & B. occidentalis \\
\hline Locality & & Brazil & Brazil & Venezuela & Guadalupe & Venezuela & Argentina \\
\hline \multicolumn{8}{|l|}{ Cercariae } \\
\hline \multirow[t]{2}{*}{ Body } & $\mathrm{L}$ & $197 \pm 12(177-218)$ & $175 \pm 13(137-205)$ & $140-180$ & $100-200$ & $183 \pm 16(158-199)$ & $187 \pm 23(135-216)$ \\
\hline & W & $75 \pm 7(67-94)$ & $68 \pm 5(55-75)$ & $60-79$ & $60-110$ & $62 \pm 4(58-66)$ & $66 \pm 4(63-72)$ \\
\hline \multirow{2}{*}{ Oral sucker } & $\mathrm{L}$ & $32 \pm 2(27-34)$ & $30 \pm 1(27-33)$ & $24-28$ & $26-30$ & $32 \pm 3(25-33)$ & $31 \pm 2(29-32)$ \\
\hline & W & $31 \pm 2(27-34)$ & $28 \pm 1(26-31)$ & - & $28-34$ & - & $31 \pm 2(29-32)$ \\
\hline Spines & $\mathrm{N}$ & 19 & 19 & $19-21$ & 19 & $19-20$ & $19-20$ \\
\hline \multirow[t]{2}{*}{ Ventral sucker } & $\mathrm{L}$ & $33 \pm 2(29-36)$ & $30 \pm 2(27-33)$ & $26-36$ & $26-32$ & $34 \pm 3(33-42)$ & $31 \pm 2(29-32)$ \\
\hline & W & $35 \pm 1(33-39)$ & $31 \pm 2(27-34)$ & - & $30-36$ & - & $31 \pm 2(29-32)$ \\
\hline \multirow[t]{2}{*}{ Tail } & $\mathrm{L}$ & $486 \pm 45(410-594)$ & $883 \pm 94(774-1,152)$ & $394-451$ & $1,100-1,400$ & $480 \pm 47(415-540)$ & $780 \pm 115(540-990)$ \\
\hline & W & $94 \pm 11(75-115)$ & $135 \pm 18(102-184)$ & $47-117$ & $150-190$ & $83 \pm 13(66-108)$ & $104 \pm 24(72-135)$ \\
\hline $\mathrm{TL} / \mathrm{BL}$ & & $4(3-5)$ & $5(4-6)$ & 3 & $10-14$ & 7 & - \\
\hline \multirow[t]{2}{*}{ Metacercariae } & $\mathrm{L}$ & $109 \pm 5(102-122)$ & $88 \pm 4(80-98)$ & $130-186$ & 85 & $100 \pm 6(84-109)$ & $78-88$ \\
\hline & W & $76 \pm 4(70-81)$ & $53 \pm 5(46-68)$ & $72-103$ & 53 & $59 \pm 6(48-67)$ & $44-52$ \\
\hline \multicolumn{8}{|l|}{ Rediae } \\
\hline \multirow[t]{2}{*}{ Body } & $\mathrm{L}$ & $985 \pm 85(887-1,195)$ & $1,577 \pm 238(1,289-2,098)$ & $376-846$ & 2,300 & $784-1,004$ & $783-1,620$ \\
\hline & W & $127 \pm 16(102-171)$ & $202 \pm 37(120-258)$ & $94-141$ & 140 & $73-122$ & $108-189$ \\
\hline \multirow[t]{2}{*}{ Pharynx } & $\mathrm{L}$ & $45 \pm 6(33-53)$ & $48 \pm 11(38-75)$ & $33-48$ & 42 & $42-50$ & $38-76$ \\
\hline & W & $40 \pm 6(32-50)$ & $50 \pm 13(38-83)$ & $24-45$ & 36 & - & $43-54$ \\
\hline \multirow[t]{2}{*}{ Caecum } & $\mathrm{L}$ & $432 \pm 77(334-614)$ & $709 \pm 204(410-1,204)$ & - & - & & - \\
\hline & W & $41 \pm 6(33-50)$ & $72 \pm 20(34-102)$ & - & - & - & - \\
\hline
\end{tabular}

The specimens of $P$. novemdecim that were obtained from T. dominicus in Brazil have smaller measurements for some body structures than those reported for the species by other authors. These differences may result from the use of uncompressed specimens in this study. Despite the noted size differences, other differential characteristics, such as the equivalent sizes of the anterior and posterior portions of the parasite, the similar widths of the cirrus pouch and the ventral sucker, the presence of vitellaria that are confluent in the region below the ventral sucker, the tandem positioning of the testes, and the arrangement and size of the collar 
spines, are in agreement with those reported for $P$. novemdecim (LUTZ, 1928; NASIR et al., 1972; FALTÝNKOVÁ et al., 2008). In addition, the specimens examined in this study have larger dimensions than those reported for $P$. argentinensis. These specimens can be further distinguished from $P$. argentinensis by a number of morphological differences, such as the presence of vitellaria that are confluent below the ventral sucker and the positioning of the cirrus sac almost entirely anterior to the ventral sucker (LUNASCHI; DRAGO, 2010). Tachybaptus dominicus is the only natural host known for $P$. novemdecim, and this is the first report of the occurrence of this parasite in Brazil.

Nasir et al. (1972) elucidated the life cycle of $P$. novemdecim in Venezuela. These authors found cercariae in Biomphalaria glabrata (Say, 1818) and obtained metacercariae and adults in P. reticulata and T. dominicus, respectively. The morphology of the Petasiger sp. 1 larvae identified in this study is similar to the morphology of $P$. novemdecim larvae, as described by Nasir et al. (1972). However, we cannot determine whether the 2 species are conspecific because adult parasites were not obtained experimentally in the present study. In fact, recovery of Petasiger species from experimental definitive hosts has proved to be a difficult task, and several other authors have been unsuccessful in recovering parasites from different laboratory models (canaries, chicks, rats, snakes, ducks, pigeons, cats, mice, and rats). Previous studies have only been able to obtain these parasites from canaries, which were often observed to have a low prevalence and intensity of infection (BEAVER, 1939; ABDEL-MALEK, 1953; NASSI, 1980; OSTROWSKI DE NÚNEZ, 1982; KOSTADINOVA; CHIPEV, 1992; KOSTADINOVA, 1997). It is expected that the advent of molecular approaches, such as those recently used to elucidate the life cycle of Petasiger islandicus Kostadinova and Skírnisson, 2007 (GEORGIEVA et al., 2012), will promote an understanding of the association between larvae and adults of different species of Petasiger, including South American species.

Another Latin American Petasiger species, Petasiger caribbensis Nassi, 1980, was obtained experimentally from canaries in Guadalupe, where B. glabrata was reported as the natural first intermediate host (NASSI, 1980). Later, Faltýnková et al. (2008), in the magnificent review of the genus Petasiger, based exclusively on adult morphology considered $P$. caribbensis to be a junior synonym of $P$. novemdecim. However, in addition to morphological differences observed between adult parasites of these species, including the disposition of the testes, which are always oblique in $P$. caribbensis and in tandem in $P$. novemdecim, these species display significant differences in the morphology of larval stages. The cercariae, metacercariae, and rediae of $P$. caribbensis are significantly larger than those described for $P$. novemdecim by Nasir et al. (1972), and we believe that such differences are sufficiently consistent for the species to be considered distinct. The cercariae and metacercariae of Petasiger sp. 2 obtained from $B$. straminea and B. tenagophila in Brazil are similar to the larvae of $P$. caribbensis and other larvae found in B. glabrata in Venezuela (OSTROWSKI DE NÚNEZ, 1982) and in Biomphalaria peregrina (d'Orbigny, 1835) and Biomphalaria occidentalis Paraense, 1981 in Argentina (OSTROWSKI DE NÚNEEZ, 1981; OSTROWSKI DE NÚÑEZ et al., 1991).
It is likely that $P$. novemdecim and other South American Petasiger species occur in places where both the intermediate and definitive hosts are present. Given the wide distribution of both $T$. dominicus and other podicipedids and mollusks of the genus Biomphalaria in the neotropics, it is possible that the diversity of Petasiger species in South America, specifically in Brazil, is underestimated. Further studies are needed to increase our understanding of the species diversity and life cycle of these parasites. In addition, characteristics of larval stages, when available, should be considered as important differential traits, as they can contribute significantly to the understanding of taxonomic issues related to these parasites.

\section{Acknowledgements}

We thank the National Council for the Development of Science and Technology (CNPq) for financial support and doctoral scholarship to HAP.

\section{References}

Abdel-Malek ET. Cercaria chandleri, a new echinostome species from the snail Helisoma corpulentum in lake Itasca, Minnesota. Trans Am Microsc Soc 1952; 71(3): 277-281. http://dx.doi.org/10.2307/3223379

Abdel-Malek ET. Life history of Petasiger chandleri (Trematoda: Echinostomatidae) from the pied-billed grebe, Podilymbus podiceps podiceps, with some comments on other species of Petasiger. J Parasitol 1953; 39(2): 152-158. PMid:13045181. http://dx.doi. org/10.2307/3274110

Beaver PC. The morphology and life history of Petasiger nitidus Linton (Trematoda: Echinostomidae). J Parasitol 1939; 25(3): 269-276. http:// dx.doi.org/10.2307/3272510

Drago FB, Lunaschi LI. Digenean parasites of ciconiiform birds from Argentina. Rev Mex Biodiv 2011; 82(1): 77-83.

Faltýnková A, Gibson DI, Kostadinova A. A revision of Petasiger Dietz, 1909 (Digenea: Echinostomatidae) and a key to its species. Syst Parasitol2008; 71(1): 1-40. PMid:18661251. http://dx.doi.org/10.1007/ s11230-008-9146-6

Georgieva S, Kostadinova A, Skirnisson K. The life-cycle of Petasiger islandicus Kostadinova \& Skirnisson, 2007 (Digenea: Echinostomatidae) elucidated with the aid of molecular data. Syst Parasitol 2012; 82(3): 177183. PMid:22711507. http://dx.doi.org/10.1007/s11230-012-9354-y

Kostadinova A. A comparative study of cercarial chaetotaxy in two species of Petasiger Dietz, 1909 (Digenea: Echinostomatidae). Syst Parasitol 1997; 37(2): 105-110. http://dx.doi. org/10.1023/A:1005777428111

Kostadinova A. Family Echinostomatidae Looss, 1899. In: Jones A, Bray RA, Gibson DI. Keys to the Trematoda. London: CAB International; 2005. v. 2, p. 9-64.

Kostadinova A, Chipev N. Experimental data on the life-cycle of Petasiger grandivesicularis Ishii, 1935 (Trematoda: Echinostomatidae). Syst Parasitol 1992; 23(1): 55-65. http://dx.doi.org/10.1007/BF00008010

Lunaschi LI, Drago FB. A new species of Petasiger (Digenea, Echinostomatidae) parasitizing Podiceps major and Rollandia rolland (Aves, Podicipedidae) from Buenos Aires Province, Argentina. Acta Parasitol 2010; 55(3): 230-234. http://dx.doi.org/10.2478/s11686010-0033-3 
Lutz A. Estudios de zoología y parasitología venezolanas. Rio de Janeiro: Published by the author; 1928.

Milward-de-Andrade R, Campos LGR. Infestação natural de Biomphalaria straminea (Dunker, 1848) por oligoquetas do gênero Chaetogaster. Rev Bras Mal Doenças Trop 1969; 21(1): 27-36.

Nasir P, Gonzalez TG, Díaz MT. Freshwater larval trematodes. XXX. Life cycle of Petasiger novemdecim Lutz, 1928. Proc Helminth Soc Wash 1972; 39(2): 162-168.

Nassi H. Données expérimentales sur le cycle biologique de Petasiger caribbensis n. sp. (Trematoda: Echinostomatidae) parasite larvaire de Biomphalaria glabrata en Guadeloupe. Ann Parasitol 1980; 55(1); 41-55.

Ostrowski de Núńez M. Fauna de agua dulce de la República Argentina. $\mathrm{X}$. Cercarias de las superfamilias Echinostomatoidea, Allocreadioidea y Microphalloidea (Trematoda, Digenea). Com Mus Arg Cienc Nat Bernardino Rivadavia 1981; 2(1): 1-9.

Ostrowski de Núńez M. Trematodos larvales de Venezuela. Cercarias pertencentes a la Superfamilia Echinostomatoidea. An Inst Biol Univ Nac Auton Mexico 1982; 52(1): 51-62.

Ostrowski de Núnez M, Hamann MI, Rumi A. Population dynamics of planorbid snails from lentic biotope in northeastern Argentina. Larval trematodes of Biomphalaria occidentalis and analysis of their prevalence and seasonality. Acta Parasitol Pol 1991; 36(4): 159-166.

Pinto HA, Melo AL. Melanoides tuberculata (Mollusca: Thiaridae) harboring renicolid cercariae (Trematoda: Renicolidae) in Brazil. J Parasitol 2012; 98(4): 784-787. PMid:22288437. http://dx.doi. org/10.1645/GE-2937.1 